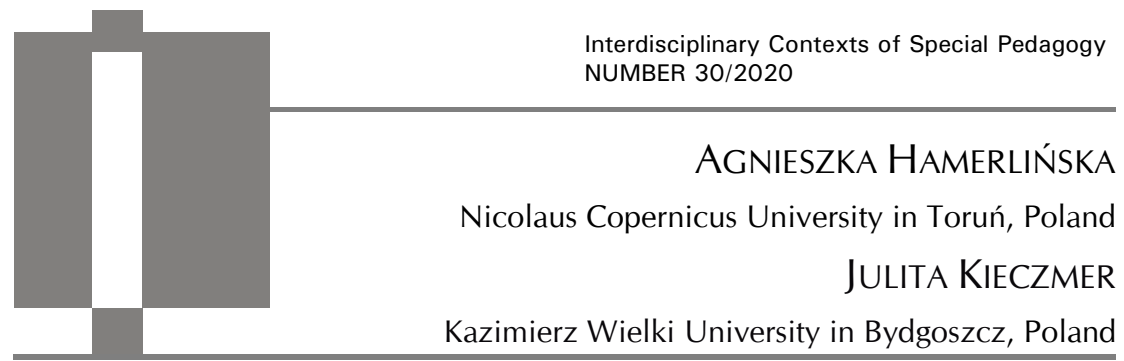

\title{
The use of the mirror in speech therapy
}

ABstract: Agnieszka Hamerlińska, Julita Kieczmer, The use of the mirror in speech therapy. Interdisciplinary Contexts of Special Pedagogy, no. 30, Poznan 2020. Pp. 285-308. Adam Mickiewicz University Press. ISSN 2300-391X. e-ISSN 2658-283X. DOI: https://doi.org/10.14746/ikps.2020.30.14

The article begins the description of the history of a mirror: its origin, creation and use. Then the characteristics of the mirror as a typical element of the speech therapy room equipment were made. The article discusses the issue of its use in the opinion of speech therapists. Speech disorders specialists note that it should be used first of all for people with articulation disorders and less for people with mutism.

KEY WORDS: mirror, speech disorders, speech therapist, speech therapy, specifications

\section{Introduction}

The mirror (Latin: speculum) is derived from the words 'zerknąc' (glance), 'spojrzeć' (look) in Polish. The same goes for Czech - zrcadto and zrkadto - and Russian - zercato and zerkało. In French (mirori) and English (mirror), it means: look, admire. ${ }^{1}$ In Italian (lustro) it

${ }^{1} \mathrm{M}$. Wallis, The history of the mirror and its role in various fields of culture (Dzieje zwierciadła i jego rola w różnych dziedzinach kultury), Łódzkie Towarzystwo Naukowe, Łódź 1956, p. 15. 
stands for glare or gloss. We can notice that all aforementioned explanations have one thing in common: the common function and intended use of the mirror (looking at one's own reflection in it).

Katarzyna Luft notes that in the practice of everyday life the mirror is simply a surface on which we see our own image. Usually regarded as an artifact used for contemplating the corporeal image, the mirror has been associated with spirituality in many aspects in the cultural \& semiotic dimension. ${ }^{2}$

The presence of the mirror in the speech therapist's room seems natural. In the therapeutic process under way, the use of each educational aid should be justified and substantively adapted to the disorder and the person concerned. When reviewing literature, it is difficult to come across guidelines on the use of the mirror in the speech therapist's room. It is usually indicated that the mirror should simply be and that its main purpose is to control the work of vocal organs.

This paper starts the outline of the history of the origin and development of the mirror from ancient times and continues it till modern times. It also contains a description of existing superstitions where the mirror plays a fundamental role. The next step was the analysis of literature on the use of the mirror in the speech therapist's room. The aim of the paper is to describe the method of use of the mirror in speech therapy by speech therapists working in Poland. On the basis of a diagnostic survey, a study was conducted in a group of 264 speech therapists. Their results and conclusions are the last part of this paper.

\section{The history of the mirror}

Originally, the function of mirrors was performed by springs, in which people could see their own reflection. Speaking of spring

${ }^{2} \mathrm{~K}$. Luft, The body trapped in mirrors: the issue of corporeality of the human being towards the discourse of the mirror in modern humanistic thought (Ciato osaczone lustrami, czyli problem cielesności istoty ludzkiej wobec dyskursu zwierciadła we wspótczesnej myśli humanistycznej), Scientific papers of the Academy of Physical Education in Wroclaw, 2012, pp. 38-44. 
reflections, it is worth quoting the figure of Narcissus - the hero of a Greek myth who fell in love with his own beauty upon seeing his own reflection in a spring. ${ }^{3}$ A less known character is Högn a prince who looked at himself in the water to check the words of people who said he looked ugly. ${ }^{4}$

Thin, round or four-sided polished stone slabs dating back to the Neolithic Age, found in Scotland, are probably the first produced mirrors. Copper of bronze polished slabs are mirrors produced in the Bronze Age. The date of making the first glass mirror is unknown. We know, however, that in the $12^{\text {th }}$ and $13^{\text {th }}$ century the method of making mirrors was already known as 'laying a thin metal sheet on the rear side of the glass ${ }^{5}$, but it was rarely put into practice. Glass mirrors were produced in Nuremberg as early as 1383. Ochsenaugen - 'ox's eyes' - is the name of small convex glass mirrors produced in Germany since the $15^{\text {th }}$ century. ${ }^{6}$

Further mirrors were medieval pocket mirrors, known and used both in the bourgeois society and among the poorer rural people. In subsequent years of the Middle Ages, free-standing mirrors, called damoyselle in French, started to appear. Wall-mounted mirrors were already known at that time ${ }^{7}$.

Mirrors have changed significantly over the centuries: from various materials and equipment used for their production to their use, which differs from the original one in many cases today (Table 1).

As early as the middle of the third millennium B.C. in Egypt, mirrors were made of metal sheet, from which the desired shape was cut and moulded (these mirrors were most often shaped like the sun, a pear or a heart). It was from Egypt that metal mirrors began to be disseminated; in subsequent periods, they became known and were produced in Mycenae or in Greece. Egyptian mir-

${ }^{3}$ R. Graves, The Greek myths, Polish translation: Mity greckie, Państwowy Instytut Wydawniczy, Warszawa 1982, p. 250.

${ }^{4} \mathrm{M}$. Wallis, The history of the mirror..., op. cit., p. 16.

${ }^{5} \mathrm{M}$. Wallis, The history of the mirror..., op. cit., p. 33.

${ }^{6}$ Ibidem.

7 Ibidem. 
Table 1. Mirror production chronology

\begin{tabular}{|c|c|c|}
\hline $\begin{array}{l}\text { Material used } \\
\text { for making mirrors }\end{array}$ & Production place & Duration \\
\hline Stone slabs & Scotland & Neolithic Age \\
\hline Copper & Elam & first half of the $3^{\text {rd }}$ millennium B.C. \\
\hline Copper and bronze & Egypt & first half of the $3^{\text {rd }}$ millennium B.C. \\
\hline Bronze & Scythia, China & $7^{\text {th }}$ century B.C. \\
\hline Metal & Greece & $7^{\text {th }}$ century B.C. \\
\hline Bronze & Among the Celts & $1^{\text {st }}$ century B.C. \\
\hline Copper and bronze & Russia & middle of the $1^{\text {st }}$ century B.C. \\
\hline Blown glass & Rome & $1^{\text {st }}$ century \\
\hline Bronze & Ukraine & From the $5^{\text {th }}$ century \\
\hline Bronze & $\begin{array}{l}\text { Among the Slavs from } \\
\text { the early Middle Ages }\end{array}$ & From the $10^{\text {th }}$ century \\
\hline Leaded glass & Western Europe & Circa 1250 \\
\hline Glass & Europe & $15^{\text {th }}$ century \\
\hline $\begin{array}{l}\text { Glass poured with amal- } \\
\text { gam (an alloy of mercury } \\
\text { with lead or tin) }\end{array}$ & Venice & Middle of the $16^{\text {th }}$ century \\
\hline $\begin{array}{l}\text { Glass, silvered on the re- } \\
\text { verse }\end{array}$ & $\begin{array}{l}\text { by Drayton, Petit-Jean } \\
\text { and Liebig }\end{array}$ & 1843 \\
\hline $\begin{array}{l}\text { Glass with aluminium } \\
\text { or silver on the back wall }\end{array}$ & & currently \\
\hline
\end{tabular}

Source: M. Wallis, The history of the mirror, op. cit., pp. 62-64.

rors were flat and convex or slightly concave, usually small (their diameter ranged from 15 to $20 \mathrm{~cm}$ ). These mirrors always contained a handle usually made of Acacia and cedar wood. A gilded or ivory handle was attached to more expensive mirrors. The mirror was a part of Egyptian women's garments for the time of worship. The possession of this item was a proof of the social status and the privilege that a woman from a higher social stratum had. Once the use of a mirror by a maidservant was impossible; because of the function 
fulfilled by her, it 'was equal to ...the overthrow of the existing order'. Mirrors were a particularly appreciated and recognised object; they were stored carefully in order not to be destroyed. They were kept in leather or wicker cases, and more valuable copies were kept in locked caskets. At the turn of the $13^{\text {th }}$ century B.C., Egyptian mirrors became prevalent in Mycenae. Here their shape was round (in contrast to shapes formed in Egypt). ${ }^{8}$

The Greek Hellenic culture, in which the beauty of the human body played a significant role, was closely connected with the use of the mirror, which also enabled people to admire human beauty. As in Egypt, the possession of a mirror in Greece was a privilege. It was intended for persons who came from the ruling classes. The possession of a mirror emphasised the status of its holder that a majority of society could not afford because of costs. In Korinth, free-standing mirrors began to appear in the middle of the $4^{\text {th }}$ century B.C., but their real prime started in the $5^{\text {th }}$ century B.C. Later mirrors were made with a cover and decorated with a relief (which was first pressed and then moulded). In almost every case, mirrors were used only by women and put into their graves after death.

In ancient Rome, all three types of mirrors produced in Greece were known: free-standing, with a handle and with a cover. Introducing modifications and focusing on functionality, the Romans started creating square and rectangular mirrors. Their production took place in the territory of current Brindisi. Unfortunately, bronze mirrors became quickly covered with blue-green or black deposit due to moisture, which eventually led to the opaqueness of beautiful polished bronze panels.

Slavic peoples inhabiting the western borders of the Slavic language area knew metal mirrors coming from Rome from the $10^{\text {th }}$ century. Made of round metal plate, these mirrors also had a handle. ${ }^{9}$

During the reign of the Chinese T'ang dynasty (618-907 A.D.), the edges of bronze mirrors were adorned with beautiful motifs of

${ }^{8}$ Erman A., Ranke H., Aegypten und aegyptisches leben im altertum, Tubigen 1923.

${ }_{9}^{9}$ Niederle L., Život starých Slovanů, vol. 1, part 1, Prague 1911. 
lions and bunches of grapes. This pattern was a sign of wealth and abundance. ${ }^{10}$

In the middle of the sixteenth century, the production of mirrors started in Venice; their back side was poured with a mixture of mercury with tin or lead - such a compound was called an amalgam. ${ }^{11}$ As we know today, mercury is a very toxic element, but this knowledge was absent in the past. Mercury was excavated by physically weaker persons or prisoners. Persons exposed to the toxicity and harmfulness of its impact survived only around three years in this environment. ${ }^{12}$ In 1861, Adolf Kussmaul - a German doctor and scientist - conducted an examination of persons who had been employed in the production of mirrors in Nuremberg and Fürth. On the basis of this examination, he wrote a work in which he described chronic mercury poisoning. At that time, mirrors were produced according to the following technology:

'The glass was first cut at an angle and coated with a tin layer, after which mercury was rubbed in by means of flannel rags. Then such a mirror was cleaned and dried to avoid the formation of air bubbles and left for the binding of the amalgam. After around 3-4 weeks, the mirror was ready'. ${ }^{13}$

The high incidence of disease among employees exposed to mercury was caused by many factors. During their work, they not only breathed in the fumes of this substance, but also their clothes were saturated with it. Such a long exposure to mercury resulted in poisoning that A. Kussmaul described in three stages:

'at first there was excessive stimulation, then the fine tremor of limbs appeared, and the cachexy of the whole body followed'.14

10 Cammann S., The lion and Grape Patterns on Chinese Bronze Mirrors, [in:] Artibus Asiae, Artibus Asiae Publishers, A 16, 1953.

11 http:/ / www.allum.pl/zagrozenia-i-alergeny/rtec

12 R. Szozda, Mercury from the earliest times till the 19 $9^{\text {th }}$ century (Rtęc od najdawniejszych czasów do wieku XIX), Atest - Ochrona pracy, no. 1, 2005, p. 38.

${ }^{13}$ R. Szozda, Mercury..., op. cit., p. 39.

${ }^{14}$ R. Szozda, Mercury..., op. cit., p. 39. 
The publication of the confirmed multitude of the harmful and toxic impact of mercury through Kaussmal's studies contributed to the adoption of very strict regulations. They specified general rules of work concerning the production of mirrors, but, most importantly, led to a change in the method of manufacturing; mercury was no longer used, being replaced with silver compounds.

The first glass mirrors had the size of a small plate. Glass was initially melted from sand that contained iron oxide - an element reducing transparency. Attempts were made to use 'sodium with potassium with an admixture of ash from fern' in glass production processes 15 , which gradually improved the quality of products after many tests.

The production of glass mirrors was not an easy task and required certain skills. The Romans mastered and used a technique based on the application of hot lead to a thin and fairly even glass layer - otherwise, if glass were thick and uneven, it would not survive such a big change in temperatures. Hot lead poured into a bubble blown from glass solidified during cooling and covered the concave part; the last stage was cutting the bubble into pieces. This method of making mirrors also meant that their size could not be big. Another drawback was the convex shape of the mirror, which deformed the reflection of the person looking in it. ${ }^{16}$

In the northern part of Europe, at the beginning of the $16^{\text {th }}$ century, mirrors were increasingly widespread. As can easily be guessed, in the first phase of their prime they appeared more and more frequently in castles, then in houses of wealthy burghers and at fairs, where they could be bought.

For a very long time, changes in the production of mirrors progressed very arduously. There were also no transformations that would make work easier for people engaged in this production. This applied also to mirrors themselves, which still were not made perfectly. The modernisation of mirror production processes oc-

${ }^{15} \mathrm{~S}$. Melchior-Bonnet, A tool of magic. The history of mirrors (Narzedzie magii. Historia luster i zwierciadet), Bellona, Warszawa 2007, p. 21.

16 Ibidem, pp. 21-22. 
curred in the $19^{\text {th }}$ century. The huge changes introduced at that time made work easier and improved that quality of products - mirrors. A blade wheel was used for grinding and polishing, and openhearth furnaces helping to obtain higher and better distributed temperatures contributed to a decrease of defects occurring in molten glass. The system of work changed significantly, too. The pouring, flattening and rolling of molten glass was improved. The reduction of the production time resulted in the better quality of the product.

The history of mirrors is connected with the making of artistic mirrors and intertwined with the history of metalworking and glassmaking, sculpture and engraving on metal, enamelling and inlay and then with the history of framing, furniture-making, interior design and architecture. ${ }^{17}$ Mirrors were put to use also in engineering and contributed to many discoveries in physics and astronomy. They have also been used for a long time in sport, ballet, dancing, cosmetology, fashion, hairdressing and speech therapy.

\section{Mirror-related superstitions}

Superstitions have played an important role in people's lives and the culture of society for a long time. ${ }^{18}$ The lexeme 'superstition' is described as 'a strongly rooted, mistaken and groundless belief; a mistaken and unjustified view on something; prejudice' ${ }^{19}$ Metelska stresses the use of the word 'erroneous' in the definition, which indicates unjustified reasons and the absence of (reasonable) grounds for belief in something. In Bruce Hood's opinion, religious beliefs are a source of various superstitions. Generally speaking, a supersti-

17 M. Wallis, The history of the mirror..., op. cit., p. 62.

${ }^{18} \mathrm{~K}$. Metelska. Superstitions and customs as factors shaping the behaviours of society (on the example of a Ukrainian wedding) (Przesady i obyczaje jako czynniki sterujace zachowaniami społeczeństwa (na przykładzie ukraińskiego wesela)). Acta Humana, 7, 2016.

${ }^{19}$ A universal dictionary of Polish (Uniwersalny słownik języka polskiego), vol. 3, ed. S. Dubisz, Warszawa 2003, p. 728. 
tion is a folk belief in the supernatural. Superstitions are connected with the social and cultural circle, as well as views taken over without a second thought from other persons - often parents or people regarded as authorities. In the Polish version of the lexeme ("przesąd'), even the name suggests that something is prejudged a priori. ${ }^{20}$ Superstitions are obviously devoid of the scientific dimension. However, when learning the history of the mirror, it is hard not to reveal surprising beliefs connected with it.

It was once believed that the mirror reflection shows human soul and that this mirror may deprive the human being of this soul. That was something in which inhabitants of Melanesia, the Zulus or the Aztecs believed. The Jewish society still cultivates the habit of covering all mirrors in the house in which a dead person is presented (the soul of the dead person that still wanders around the house cannot see him, or an inhabitant of the house cannot see it). The same occurs in Muslim religion. ${ }^{21}$

There is also a very popular belief that breaking a mirror brings bad luck for seven years. ${ }^{22}$ There are many theories how to get rid of this bad luck. The most popular suggestion is to throw that mirror out of the house as quickly as possible. Another one is to wrap the broken item in paper, stand with one's back towards the water and throw it into the water. In older collections, we can also find information that if a broken mirror was a souvenir, it could not be thrown out, but in order to avoid bad luck, it was necessary to hide

20 A. Grzywa, Manipulation. Everything you should know about it (Manipulacja. Wszystko, co powinieneś o niej wiedziec), Lublin 2013, p. 40.

${ }^{21} \mathrm{~K}$. Luft, The body trapped in mirrors: the issue of corporeality of the human being towards the discourse of the mirror in modern humanistic thought (Ciato osaczone lustrami, czyli problem cielesności istoty ludzkiej wobec dyskursu zwierciadła we wspótczesnej myśli humanistycznej), Scientific papers of the Academy of Physical Education in Wroclaw 2012, pp. 38-44.

22 E. Krajewska-Kułak, P. Radziejewski, K. Van Damme-Ostapowicz, J. Lewko, Barbara Jankowiak, B. Kowalewska, K. Wróblewska, J. Chilińska, E. Ortman, A. Moczydłowska, Attitudes of adults and young people to traditional superstitions and prejudices (Postawy dorostych $i$ młodzieży wobec tradycyjnych przesąów i zabobonów), Problemy Higieny i Epidemiologii, 2011, 92(3), pp. 441-450. 
the mirror and it was no longer possible to look at one's own reflection in it. 23

In the folk culture of Warmia, a number of prohibitions and requirements was observed for the sake of protection against ghosts; for example, entering the barn bareheaded or washing the dishes after Thursday supper was forbidden. In order to make a ghost believe that nobody is home, the inhabitants of Warmia placed shoes towards the door and laid a sheaf of hay on the bed or slept in a position different than usual. It was also believed that a ghost is afraid of a mirror hung in the barn. ${ }^{24}$

Although Internet portals are not a source of scientific knowledge, it is worth noting widely available superstitions. The mirror seems to be in the centre of created superstitions. Many parents still have a dilemma whether to show their child's reflection to it before it is one year old, and they experience even bigger stress when their child has not been baptised yet. Some parents believe that their child is exposed to the devil's actions before it is baptised. Even today, many villagers are still convinced that a child may see the devil in the mirror upon seeing its own reflection before the baptism ${ }^{25}$. Moreover, there is a superstition that if a child will often see its reflection in a mirror, it may begin to stutter. ${ }^{26}$ There is also a belief among people that infants should not be shown a mirror, because if a child sees its own reflection in a mirror, it may drown in the future. ${ }^{27}$

\section{The mirror in the speech therapist's room}

A study on the professional and social image of the speech therapist conducted by Zbigniew Tarkowski showed that, according to

${ }^{23}$ Ibidem, p. 80.

${ }^{24} \mathrm{R}$. Kaczorowski, Superstitions and beliefs in the folk culture of Polish inhabitants of the Warmia region at the turn of the 20 th century (Przesady $i$ wierzenia w ludowej kulturze polskich mieszkańców Warmii na przełomie XIX i XX wieku). Studia Elbląskie, V, 2003.

${ }^{25}$ https://www.sosrodzice.pl/dziecko-a-lustro/, access: 22nd July 2020.

${ }^{26}$ https://www.rodzice.pl/temat/przesad-z-lustrem/, access: 22nd July 2020.

${ }^{27}$ http:/ / www.nowiny.rybnik.pl/artykul,42115,przesady-zwiazane-z-lustrem. html, access: 22 ${ }^{\text {nd }}$ July 2020. 
$92.5 \%$ of respondents, 'the speech therapist is associated with a woman sitting in front of a mirror and calling out sounds' ${ }^{28}$ Although this study was performed many years ago, and the profession of speech therapist has intensely developed, both the speech therapist and the speech therapy room are still associated with the mirror. It must be acknowledged that the mirror is the speech therapist's main professional attribute.

According to the Ordinance of the Minister of Health of $6^{\text {th }}$ November 2013 on guaranteed benefits within the scope of therapeutic rehabilitation that was published in the Journal of Laws of the Republic of Poland on 12th December 2013, each speech therapy room where a therapy is conducted should contain a speech therapy mirror or a control mirror. According to the act, the speech therapy mirror is an obligatory part of each speech therapy room where the rehabilitation of persons with a hearing and speech dysfunction is conducted, whereas the control mirror must be put in each room intended for the therapy of children with developmental age disorders. However, there is more than one existing model of a speech therapy room. ${ }^{29}$

A few types of mirrors are recommended for the speech therapist's room:

1. Horizontally hanging mirror - the most frequent, rectangular type of mirror hanging on the wall in front of the child and the speech therapist. Its huge advantage is that faces of persons undergoing therapy are very well visible. Unfortunately, it may reflect various objects located in the room, which may distract the patient's attention.

2. Free-standing table mirror - less popular in speech therapy rooms; it is of average size and can be freely put aside. Unfor-

${ }^{28}$ Z. Tarkowski, The professional and social image of the speech therapist (Wizerunek zawodowy i spoteczny logopedy), [in:] Speech therapy: theory and practice (Logopedia teoria i praktyka), Agencja Wydawnicza a linea, Wrocław 2005, p. 397.

${ }_{29}$ A. Walencik-Topiłko, The speech therapy room - the therapist's professional knowledge and practices (Gabinet logopedyczny - warsztat pracy terapeuty), [in:] The fundamentals of neurological speech therapy. An academic handbook (Podstawy neurologopedii. Podręcznik akademicki), 2005, pp. 328-343. 
tunately, it is possible to see only one person in the reflection. While holding the mirror, the patient does not see the speech therapist and vice versa.

3. Pocket mirror - used most frequently during group sessions, so that each participant would have access to his/her own mirror. Unfortunately, the whole face of the practising person cannot be seen in such a mirror, so it must be held manually during the therapy.

4. Double-wing mirror - additional side mirrors allow the therapist to observe the practising person from a half-profile, and they can be closed when the use of the mirror is not required during an exercise. The size of the mirror is a drawback - it occupies much space. ${ }^{30}$

Functions of the mirror in the speech therapist's room are as follows:

- it helps to build a therapeutic bond between the patient and the speech therapist;

- it is a diagnostic tool (used for the examination of hypernasality);

- it is used as a means for controlling the patient and for his self-control;

- it acts as an auto-corrector;

- it can be treated as a tool supporting the development of imitation.

The first element worth attention is the role of the mirror is the construction of a therapeutic bond between the patient and the speech therapist. Watching each other in front of the mirror may be even an intimate activity; it is an act where one person opens up to another. If the meeting takes place in front of this tool, and the speech therapist and the patient sit beside each other, there is a risk that the therapist will enter the sphere of the patient's mental comfort too violently. Ensuring comfort is connected with keeping and respecting a physical distance towards the patient. The physical distance is a 'personal space and an invisible changeable border that

${ }^{30}$ Ibidem. 
regulates the distance at which we establish relations with other persons' ${ }^{31}$ The interpersonal distance, particularly in the first phase of establishing contact, gives a chance to develop a relation that is safe for the patient. The physical distance remains connected with the psychological distance, which is understood as a level of intimacy and closeness between interlocutors, depends on the dynamic self-disclosure process and occurs on the cognitive level - comprehension, the emotional level - empathy and the behavioural level listening, communication. ${ }^{32}$ The typical distance during a conversation is the distance of an outreached hand. It is worth keeping these guidelines in mind particularly during the speech therapy diagnosis process. Sometimes it is not worth reducing the distance between the patient and the speech therapist at once by inviting the patient to sit beside the therapist in front of the mirror. The verification of the build and fitness often does not need a mirror (for example, laryngologists do not evaluate the build of the mouth in front of the mirror).

The mirror as a therapeutic tool plays a significant role in conducting the therapy of persons with dyslalia, hypernasality, autism spectrum disorders, speech disfluency, facial nerve paralysis and hearing disorders, which will be explained below.

The mirror in the speech therapy room is used mainly for controlling purposes. Therapists treat mirrors as a tool for observing the biofeedback mechanism, because when they speak a sound or perform a face exercise, they can observe their own intentions and their implementation. ${ }^{33}$ The mirror is most useful during a demonstration of the proper positioning of speech organs. It creates the possibility of comparing the performance of exercises and is useful in calling out sounds.

${ }^{31}$ P. Bell, T. Greene, J. Fisher, A. Baum, Environmental psychology (Psychologia środowiskowa), GWP, Gdańsk, 2004, p. 345.

32 A. Suchańska, Conversation and observation in psychological diagnosis (Rozmowa i obserwacja w diagnozie psychologicznej), WAiP, Warszawa, 2007, p. 231.

33 A. Grossinho, S. Cavaco, J. Magalh, An interactive toolset for speech therapy. 
The small cosmetic mirror is a diagnostic tool that helps to check if hypernasality occurs in the patient. If the mirror mists up, this means that the air escapes through the nose, which proves the existence of hypernasality (in the case of non-nasal sounds, the air escapes through the mouth and the mirror should not mist up). This kind of examination is called a mirror test. ${ }^{34}$

It also turns out that the mirror is used as a tool for teaching imitation in children with autism spectrum disorders. Autistic persons often show deficits in imitation skills ${ }^{35}$, and imitation is a prerequisite for the development of successive development stages, including social communication skills. It has been noticed that Video Self Modelling is treated as an effective imitation teaching method, but it involves high costs and requires the adaptation of rooms. Studies were conducted with the use of mirrors as a new treatment method improving imitation skills in children diagnosed with autism spectrum disorders. In the opinion of authors of the project, the use of the mirror allows participants to observe their engagement in a specific behaviour; at the same time, mirrors save more time and money than the VSM method does. The use of mirrors lead to the improvement of imitation skills in persons with autism spectrum disorders, both in school and at home. In addition, it allows patients to imitate movement and voice. ${ }^{36}$

The mirror is also used in the therapy of persons with speech disfluency. It primarily helps the patient to observe himself/herself during the occurrence of blocks and teaches them to maintain eye contact with himself/herself. It is recommended to use a relatively large mirror (in which persons see themselves from the waist up) that can be moved and put in the place where the patient is. Talking

${ }^{34}$ C.J. Crowley, M. Baigorri, M.S. Sommer, Cleft Palate Speech and Feeding Train the Trainer, LEADER Sproject.org Teachers College, Columbia University, 2016.

${ }^{35}$ C.M. Freitag, C. Kleser, A. Gontardf, Imitation and language abilities in adolescents with autism spectrum disorder without language delay. European Child \& Adolescent Psychiatry, 15(5), 2206, pp. 282-291.

$36 \mathrm{~V}$. Woude, Chelsea, Examining the Effects of a Mirror on Imitation in Children with Autism, Honors, Theses. Paper 2311, 2013. 
and observing oneself during a phone conversation is recommended. The mirror is useful in allowing the individual to understand his/her audible and visible speech disorders. The patient is advised to perform exercises: reading in front of the mirror, looking at himself/herself, paraphrasing sentences and maintaining eye contact. ${ }^{37}$

In the therapy of children with hearing disorders, a system consisting of a mirror, a microphone, an amplifier (Pocketalker® PKT C1 Model) and headphones is used during speech training sessions at school. During exercise, the speech therapist and the pupil sit beside each other, looking into the mirror placed in front of them. The therapist holds the microphone and the pupil wears headphones. The audio file from the microphone is reinforced and sent to the pupil's headphone. When the therapist is talking, the child with a hearing deficit hears his/her voice in the headphone and sees the movement of lips in the mirror. ${ }^{38}$

The mirror is also a necessary tool during the facial nerve paralysis therapy. In the rehabilitation process, self-control is of huge importance, and the mirror plays a fundamental role because, in combination with the neuromuscular therapy, it facilitates visual feedback for the purpose of controlling movements during exercises. ${ }^{39}$ This strategy triggers the plasticity of the brain (the central nervous system is believed to be plastic and this quality remains active for the whole human life). The motor cortex is able to reorganise itself in response to the training of tasks. Thus, the voluntary control of movements allows for neuron reprogramming 40 , thereby ensuring

37 Ibidem.

38 S. Nanayakkara, L. Wyse, E. Taylor, The haptic chair as a speech training aid for the deaf, Proceedings of the $24^{\text {th }}$ Australian Computer-Human Interaction Conference, 2012, pp. 405-410.

${ }^{39}$ R. Cury, M.L. Fouquet, P.R. Lazarini, Reabilitação da paralisia facial periférica por biofeedbackeletroneuromiográfico, [in]: Lazarini P.R., Fouquet M.L. Paralisia facial: avaliação, tratamento e reabilitação. São Paulo, Lovise, 2006, pp. 177-180.

${ }^{40}$ M.L. Fouquet, D. Serrano, I. Abbud, Reabilitação fonoaudiológica na paralisia facial periférica: fase flácida e de recuperação do movimento, [in]: P. Lazarini, M. Fouquet. Paralisia facial: Avaliação, tratamento e reabilitação. São Paulo, Lovise; 2006, pp. 149-159. 
harmonious and symmetrical movements. For this reason, the use of the mirror is necessary during each session, and using the same procedure at home is recommended to the patient.

In literature there is actually no clear guidelines for which speech disorders the use of the mirror is recommended and for which it should be avoided. There is also no information what should be done with the mirror when it is not in use and whether its steady presence may disturb the therapeutic process. Moreover, literature lacks suggestions concerning technical specifications of mirrors that should be used in speech therapy rooms with regard to specific speech disorders.

\section{Research project}

The subject-matter of the study concerned was the use of the mirror in speech therapy. The theoretical aim was to present the method of use of this educational tool by speech therapists. The quantitative research strategy was adopted. The following main research question and seven specific questions were formulated:

1. How is the mirror used in speech therapy by speech therapists?

1.1. For which speech disorders do speech therapists use the mirror as a therapeutic tool?

1.2. In the case of which speech disorders speech therapists do not consider it advisable to use the mirror during speech therapy?

1.3. Is the patient's age the factor that determines the use of the mirror in speech therapy?

1.4. For what purpose do speech therapists use a mirror during speech therapy?

1.5. What is the method of use of the mirror in speech therapy by speech therapists?

1.6. What are the technical specifications of mirrors used in speech therapy by speech therapists? 
1.7. How many stations do speech therapists have in their room to conduct speech therapy?

The diagnostic survey was used as a research method, the survey questionnaire was used as a technique, and the questionnaire prepared by researchers served as a tool. The sampling was random, the request for participation in the study was sent to members of speech therapy groups, and the survey questionnaire was filled by volunteers. The survey questionnaire was available for a period of one month. 264 speech therapists took part in the study. The group consisted of women only. The age group of respondents was 22-62 years, and the average age was 32 years. Respondents were employed in various places; some of them worked in more than one place. The largest group that took part in the study comprised speech therapists working in kindergartens/nurseries (59.8\%) and the second largest group consisted of speech therapists working in private rooms and having their own speech therapy practice (33.3\%). Other participants of the study included speech therapists who conducted therapy in mainstream schools $(33.3 \%)$, as well as those working in special schools $(15.9 \%)$ and educational-psychological counselling centres $(17.6 \%)$. Among the respondents, there were also speech therapists who worked in medical counselling centres and hospitals (8.7\%).

\section{Results of the study}

The main research question of the research project in question concerned the use of the mirror by speech therapists in speech therapy. $96 \%$ of respondents said that the mirror is used by them during speech therapy, and only $4 \%$ answered that they do not use the mirror.

\section{The use of the mirror in speech therapy vs. speech disorders}

For speech therapy practitioners, it is interesting to obtain a suggestion concerning speech disorders for which the use of the mirror is recommended. A vast majority of respondents (98\%) answered that 
they use the mirror when conducting the therapy of persons with dyslalia, 58\% use the mirror during the therapy of persons with extrinsic speech development retardation and 27\% use it during the therapy of persons with intrinsic speech development retardation caused by intellectual disability factors. $32 \%$ of respondents use the mirror for conducting the therapy of persons with aphasia/dysphasia and the same percentage of specialists use it for the therapy of persons with dysarthria/anarthria. The speech therapy of persons with specific language development disorders is conducted in front of the mirror by $20 \%$ of speech therapists, and the therapy of persons with communication disorders caused by autism spectrum factors is carried out in the front of the mirror by $24 \%$ of therapists. A slightly smaller group of respondents $(23 \%)$ conduct the therapy of persons with speech fluency disorders in front of the mirror. The mirror is used for the therapy of persons with muteness by $11 \%$ of speech therapists and for the therapy of persons with dysphonia/aphonia by $5 \%$ of them. The least frequent use of the mirror occurs in the therapy of persons with schizophasia (3\%). The results of the study suggest that the mirror is a commonly used tool in the therapeutic process.

For the purpose of building standards of good speech therapy practices the necessary opinion was the one concerning indications whether there are any speech disorders for which the use of the mirror is not recommended. $13 \%$ of respondents believe that the mirror should not be used for the speech therapy of persons with autism spectrum disorders, whereas $6 \%$ think that the mirror is not recommended for the therapy of persons with muteness. Another group - 7\% - consists of speech therapists who think that the use of the mirror in speech therapy depends on the individual patient and should not be dependent on the type of speech disorder. 3\% of respondents admitted that they did not have the knowledge that would disqualify the usability of the mirror in therapy, and $4 \%$ thought that speech therapy should not be conducted in front of the mirror in the case of patients with schizophasia and speech fluency disorders. It is important, however, that no substantive grounds for such an approach were specified. 
The presence of the mirror and spending time in front of it may produce various emotions: from embarrassment to enchantment. Not everyone spends the same amount of time in front of the mirror and using it is not natural to everyone. Respondents were asked if the patients' age also has an impact on the decision to use the mirror for therapy. $83 \%$ of respondents answered that the patient's age is not important for the decision to use the mirror during speech therapy, whereas $17 \%$ of therapists answered that their decisions are influenced by the criterion of age. The group included also persons who remarked that the mirror distracts the attention of small children, which makes it difficult to perform tasks (6\%). It was also noticed that the mirror causes embarrassment in teenagers and adults.

The participants of the study were also asked what happens to the mirror when it is not used. According to the results, $30 \%$ of respondents have another place of therapy without a mirror, 33\% do nothing with the mirror, treating it as a decorative part of their room and simply sitting in front of it, $18 \%$ cover the mirror when not using it, and $15 \%$ hide the mirror.

\section{Advisability of use of the mirror}

The advisability of tools used for speech therapy is an important factor in the planning of such therapy: $94 \%$ of respondents use the mirror when presenting position of articulation organs for calling out a sound, $84 \%$ use the mirror for exercises of articulation organs, $29 \%$ perform breathing exercises in front of the mirror and $10 \%$ conduct all activities in front of the mirror without any specific justification, $2 \%$ believe that the mirror makes the child's self-control easier, $1 \%$ use the mirror for correcting the posture of the patient's body, $1 \%$ use it for fun and for teaching the recognition of emotions, less than $1 \%$ of persons admitted that they use the mirror for relaxation (without describing the method), during the training of eating (not fully specified, either) and for eye contact and imitation exercises. 


\section{Method of use of the mirror}

In order to establish proper contact with the patient, it is important to assume the right position of the body and to determine the mutual positioning of interlocutors. This is regarded as particularly important in psychological therapy. The use of the mirror makes it necessary to assume a certain position of the body.

$73 \%$ of respondents assume a parallel position when using the mirror, whereas $27 \%$ sit perpendicular to the mirror. Speech therapists determined also the position of patients towards the mirror: $74 \%$ of patients assume a parallel position towards the mirror when conducting therapy, and $26 \%$ of patients assume a perpendicular position of the body towards the mirror.

\section{Technical specifications of mirrors used by speech therapists}

A vast majority of speech therapists - 89\% - use a rectangular mirror when conducting speech therapy, $8 \%$ use an oval mirror and $6 \%$ use a square mirror.

With regard to the size of the mirror, $74 \%$ of respondents answered that they have a medium-sized wall-mounted mirror in which two persons can see themselves, 19\% use a large mirror (e.g., a double-wing or free-standing mirror) and $7 \%$ use a small cosmetic mirror that can be held in the hand.

\section{Number of stations for conducting speech therapy in the speech therapy room}

In order to achieve the best results of speech therapy, it is important to use proper tools. The arrangement of the speech therapy room plays an important role in reaching this goal. According to the presented study, speech therapists note that there are speech disor- 
ders for which therapy in front of the mirror is not recommended. It was, therefore, natural to ask them if they have more than one workstation in their room. The analysis of the survey questionnaire shows that:

- $66 \%$ of speech therapists have a desk, chairs and a mirror,

- $56 \%$ of therapists have a small (child's) table with small chairs and a mirror,

- $19 \%$ of persons have small tables and chairs (without a mirror),

$-16 \%$ of specialists have a desk and chairs (without a mirror),

$-37 \%$ of therapists have a playing mat on the floor, and 55\% have a carpet,

$-14 \%$ of therapists have a (big) table and chairs.

None of the speech therapists mentioned having a couch.

\section{Conclusions and summary}

The mirror is treated as an attribute of the profession of speech therapist. The growing demand for help provided by speech therapists and the multitude of disorders around which therapy standards are elaborated forces us to verify the available teaching tools. The mirror as a working tool fulfils many important functions in speech therapy.

The following conclusions can be drawn from the completed study:

1. The mirror is an important therapeutic tool of speech therapists.

2. Speech therapists recommend the use of the mirror mainly during the therapy of persons with dyslalia. They recognise its important role as a device that stimulates self-control and self-correction.

3. In the opinion of speech therapists, there are speech disorders for which exercises using the mirror are not recommended. Among such speech pathologies, respondents mentioned mainly those where difficulties in establishing social communication are the main symptom (e.g., muteness, autism spec- 
trum, speech disfluency, schizophasia). Therapists did not provide any justification for this kind of approach. It is worth noting that this approach is not consistent with speech therapy standards presented in the theoretical part of this paper.

4. Speech therapists use mainly a medium-sized wall-mounted rectangular mirror in which both the patient and the therapist can see each other. Such a solution helps to establish a common field of concentration. Therapists sometimes use small cosmetic mirrors in order to explain the position of articulation organs more precisely to patients.

5. In the opinion of speech therapists, the use of the mirror should be adapted primarily to the needs of the individual patient, and the decision to use the mirror should result from the functioning of the patient in the disorder he/she has been diagnosed with. Speech therapists are quite unanimous in saying that if a patient avoids work in front of the mirror, it is proper to respect his attitude and abandon this kind of therapy.

6. Speech therapists often have more than one workstation. It is usually a desk with chairs and a mirror, but they have also small tables adapted to younger patients.

7. Respondents did not take the diagnostic function of the mirror into account when examining hypernasality.

The position of the mirror in the speech therapist's room is very important and there are grounds for using it on the basis of completed studies. At the same time, it is worth noticing that there are no clear guidelines as to the method of use and technical specifications of the mirror. Many speech therapists act intuitively and adapt the mirror both to their own needs and the patient's needs.

\section{References}

Bell P., Greene T., Fisher J., Baum A., Psychologia środowiskowa, GWP, Gdańsk 2004 , p. 345.

Cammann S., The lion and Grape Patterns on Chinese Bronze Mirrors, [in:] Artibus Asiae A.16, Artibus Asiae Publishers, 1953. 
Crowley C.J., Baigorri M., Sommer M.S., Cleft Palate Speech and Feeding Train the Trainer, LEADER Sproject.org Teachers College, Columbia University, 2016.

Cury R., Fouquet M.L., Lazarini P.R., Reabilitação da paralisia facial periférica por biofeedbackeletroneuromiográfico, [in]: Lazarini P.R., Fouquet M.L., Paralisia facial: avaliação, tratamento e reabilitação. São Paulo, Lovise, 2006, pp. 177-180.

Dunaj B., Słownik współczesnego języka polskiego, Wydawnictwo Wilga, Warszawa 1996.

Erman A., Ranke H., Aegypten und aegyptisches leben im altertum, Tubigen 1923.

Fouquet M.L., Serrano D., Abbud I., Reabilitação fonoaudiológica na paralisia facial periférica: fase flácida e de recuperação do movimento, [in]: P. Lazarini, M. Fouquet. Paralisia facial: Avaliação, tratamento e reabilitação. São Paulo, Lovise; 2006, pp. 149-159.

Freitag C.M., Kleser C., Gontardf A., Imitation and language abilities in adolescents with autism spectrum disorder without language delay. European Child \& Adolescent Psychiatry, 15(5), 2206, pp. 282-291.

Graves R., Mity greckie, Państwowy Instytut Wydawniczy, Warszawa 1982.

Grzywa A., Manipulacja. Wszystko, co powinieneś o niej wiedzieć, Lublin 2013.

Kaczorowski R., Przesądy i wierzenia w ludowej kulturze polskich mieszkańców Warmii na przełomie XIX i XX wieku. Studia Elbląskie, V, 2003.

Krajewska-Kułak E., Radziejewski P., Van Damme-Ostapowicz K., Lewko J., Jankowiak B., Kowalewska B., Wróblewska K., Chilińska J., Ortman E., Moczydłowska A., Postawy dorosłych i młodzieży wobec tradycyjnych przesądów i zabobonów, Problemy Higieny i Epidemiologii, 2011, 92(3), pp. 441-450.

Luft K., Ciało osaczone lustrami, czyli problem cielesności istoty ludzkiej wobec dyskursu zwierciadła we współczesnej myśli humanistycznej, Scientific papers of the Academy of Physical Education in Wroclaw, 2012.

Malcolm F., Self-therapy for the stutterer, Stuttering Foundation of America, 2010.

Melchior-Bonnet S., Narzędzie magii. Historia luster i zwierciadeł, Bellona Warszawa, Warszawa 2007.

Metelska K. Przesądy i obyczaje jako czynniki sterujące zachowaniami społeczeństwa (na przykładzie ukraińskiego wesela). Acta Humana, 7, 2016.

Nanayakkara S, Wyse L., Taylor E., The haptic chair as a speech training aid for the deaf, Proceedings of the $24^{\text {th }}$ Australian Computer-Human Interaction Conference, 2012, pp. 405-410.

Niederle L., Život starých Slovanů, vol. 1, part 1, Prague 1911.

Suchańska A., Rozmowa i obserwacja w diagnozie psychologicznej, WAiP, Warszawa 2007, p. 231.

Szozda R., Rtęć od najdawniejszych czasów do wieku XIX, “Atest -Ochrona pracy” no. $1 / 2005$.

Tarkowski Z., Wizerunek zawodowy i społeczny logopedy, [in:] Logopedia teoria i praktyka, Agencja Wydawnicza a linea, Wrocław 2005. 
Uniwersalny słownik języka polskiego, vol. 3, ed. S. Dubisz, Warszawa 2003, p. 728. Walencik-Topiłko A., Gabinet logopedyczny - warsztat pracy terapeuty, [in:] Podstawy neurologopedii. Podręcznik akademicki, 2005, pp. 328-343.

Woude V, Chelsea, Examining the Effects of a Mirror on Imitation in Children with Autism, Honors, Theses. Paper 2311, 2013. 